\title{
Actinomyces graevenitzii sp. nov., Isolated from Human Clinical Specimens
}

\author{
CRISTINA PASCUAL RAMOS, ${ }^{1}$ ENEVOLD FALSEN, ${ }^{2}$ NEREA ALVAREZ, ${ }^{1}$ \\ EVA ÅKERVALL, ${ }^{2}$ BERIT SJÖDÉN, ${ }^{2}$ AND MATTHEW D. COLLINS ${ }^{1 *}$ \\ Department of Microbiology, BBSRC Institute of Food Research, Reading Laboratory, \\ Reading RG6 6BZ, United Kingdom, ${ }^{1}$ and Culture Collection, Department \\ of Clinical Bacteriology, University of Göteborg, Göteborg, Sweden ${ }^{2}$
}

\begin{abstract}
Four strains of a previously unknown, catalase-negative, facultatively anaerobic, gram-positive, rod-shaped organism originating from humans were characterized by biochemical, chemical, and molecular taxonomic methods. The four strains phenotypically closely resembled one another, and although they possessed characteristics consistent with membership in the genus Actinomyces, they differed from all previously recognized species of this genus. The results of comparative 16S rRNA gene sequencing studies demonstrated that the unknown human bacterium was phylogenetically a member of the genus Actinomyces. Within the genus Actinomyces, the unidentified bacterium formed a loose, but statistically significant, association with a subgroup which included Actinomyces bovis, the type species of the genus. 16S rRNA sequence divergence values of $>6 \%$, however, unequivocally demonstrated that the unidentified bacterium represents a new subline of the genus Actinomyces. A new species, Actinomyces graevenitzii, is proposed for the four new isolates. The type strain of $A$. graevenitzii is CCUG 27294.
\end{abstract}

The genus Actinomyces as presently defined (10) is a group of facultatively anaerobic, asporogenous, gram-positive, nonacid-fast, rod-shaped organisms which generally exhibit various degrees of branching. Species of the genus Actinomyces have a broad range of biochemical and physiological characteristics and are primarily found in association with humans and animals (10, 11). In Bergey's Manual of Systematic Bacteriology (10), 12 Actinomyces species (2 of which were designated species insertae sedis) were listed. In recent years there has been a growing interest in the role of Actinomyces spp. and related gram-positive, high-G+C-content, asporogenous organisms as opportunistic pathogens of humans. As a result of this increased clinical interest, combined with improvements in the taxonomic methods used for characterizing such organisms, a plethora of new Actinomyces spp. from human sources have been described in the past few years; these new species include Actinomyces bernardiae (5), Actinomyces georgiae (7), Actinomyces gerencseriae (7), Actinomyces neuii (4), Actinomyces turicensis (13), and Actinomyces radingae (13). In this paper we report the phenotypic and phylogenetic characterization of four strains of a previously unknown Actinomyces-like bacterium from human sources. Based on the taxonomic results presented below, a new species, Actinomyces graevenitzii, is described.

Four human clinical isolates (CCUG 27294 ${ }^{\mathrm{T}}$, CCUG 29516, CCUG 32536, and CCUG 35697) were referred to the Culture Collection of the University of Göteborg (CCUG), Göteborg, Sweden, for identification. Strain CCUG $27294^{\mathrm{T}}$ originated from bronchus brush from a 57-year-old female, strain CCUG 29516 originated from a bronchial secretion from a 44-year-old female, strain CCUG 32536 originated from sputum from a 46-year-old patient, and strain CCUG 35697 originated from the jaw of a 27 -year-old male patient with osteitis. The isolates were biochemically characterized by using the API ZYM (en-

\footnotetext{
* Corresponding author. Mailing address: Department of Microbiology, Institute of Food Research, Earley Gate, Whiteknights Road, Reading RG6 6BZ, United Kingdom. Phone: (44) 118 9357000. Fax: (44) 118 9267917. E-mail: david.collins@bbsrc.ac.uk.
}

zymatic profiling), API Coryne (identification of coryneform bacteria), API 5OCH (carbohydrate fermentation), and Rapid ID $32 \mathrm{~A}$ (identification of anaerobes) systems according to the instructions of the manufacturer (API bioMérieux, Marcy l'Etoile, France). End products of glucose metabolism were determined as described by Funke et al. (3). Cellular fatty acid analyses were conducted by preparing fatty acid methyl esters and analyzing them by high-resolution capillary gas chromatography as described by Vandamme et al. (12). For polyacrylamide gel electrophoresis (PAGE) of whole-cell proteins, most of the strains examined were grown on horse blood agar ( $\mathrm{Co}$ lumbia base) at $37^{\circ} \mathrm{C}$ in the presence of $5 \% \mathrm{CO}_{2}$; the only exception was strain CCUG $18307^{\mathrm{T}}$ (Actinomyces israelii), which was grown under anaerobic conditions. The PAGE analysis was performed as described previously (9). For densitometric analysis, normalization, and interpretation of protein patterns the Gelcompar GCW 3.0 software package (Applied Maths, Kortrijk, Belgium) was used. A phylogenetic analysis was performed by comparing $16 \mathrm{~S}$ rRNA gene sequences. A large fragment of the 16S rRNA gene was amplified by PCR with universal primers pA (5'-AGAGTTTGATCCTGGCTC $\mathrm{AG})$ and $\mathrm{pH}^{*}$ (5'-AAGGAGGTGATCCAGCCGCA). The PCR products were purified with a Prep-A-Gene kit (Bio-Rad, Hercules, Calif.) according to the manufacturer's instructions and were directly sequenced by using a Taq DyeDeoxy terminator cycle sequencing kit (Applied Biosystems, Foster City, Calif.) and an automatic DNA sequencer (model 373A; Applied Biosystems). The closest known relatives of the new isolates were determined by performing a database search with the program FASTA of the Genetics Computer Group package (1). These sequences and those of other known related strains were retrieved from the EMBL and Ribosomal Database Project data libraries and were aligned with the newly determined sequences by using the program PILEUP (1). The resulting multiple sequence alignment was corrected manually, and approximately 100 bases at the $5^{\prime}$ end of the rRNA were omitted from further analyses because of alignment ambiguities. A continuous stretch of 1,320 bases was used for the distance matrix analysis. A distance matrix was calculated by using the programs PRETTY (1) and DNADIST (using the 


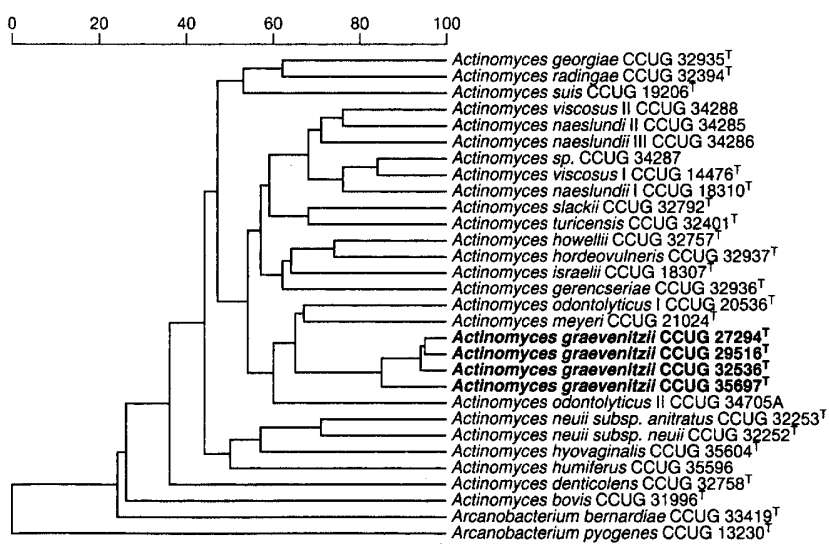

FIG. 1. Similarity dendrogram based on whole-cell protein patterns of Actinomyces graevenitzii sp. nov. and related species. Levels of correlation are expressed as percentages of similarity.

Kimura-2 correction parameter) (2). A phylogenetic tree was constructed by using the neighbor-joining method with the program NEIGHBOR (2). The stability of the groups was estimated by performing a bootstrap analysis ( 500 replications) with the programs DNABOOT, DNADIST, NEIGHBOR, and CONSENSE (2). A parsimony analysis was also performed by using the same data set (2).

The four human clinical isolates were gram-positive, nonmotile, non-spore-forming, non-acid-fast bacteria. The cells were straight to slightly curved rods with some branching and sometimes had swollen ends. Colonies on horse blood agar were approximately $0.2 \mathrm{~mm}$ in diameter after $24 \mathrm{~h}$ of incubation at $37^{\circ} \mathrm{C}$ in an atmosphere containing 5 to $10 \% \mathrm{CO}_{2}$. During the initial cultivation all of the strains adhered very strongly to the agar surface. The adherence was less after repeated subculturing. The strains were facultatively anaerobic and produced acid from glucose and some other sugars. Lactic acid and smaller amounts of succinic acid were the major end products of glucose fermentation. The strains were catalase negative and did not hydrolyze hippurate, esculin, or urea. They did not reduce nitrate to nitrite. The whole-cell protein profiles of the four unknown strains were determined by sodium dodecyl sulfate-PAGE. A dendrogram derived from a numerical analysis of the protein profiles is shown in Fig. 1. All four strains grouped together and formed a distinct branch with a within-group correlation level of more than $80 \%$. These data demonstrate that the unknown strains represent a phenotypically homogeneous group and that they are distinct from all of the other Actinomyces and Arcanobacterium spp. examined.

To establish the phylogenetic affinities of the clinical isolates, partial 16S rRNA gene sequences were examined. The sequence of a large fragment $(>1,400$ nucleotides) from strain CCUG $27294^{\mathrm{T}}$ and the sequences of short fragments $(>700$ nucleotides) from strains CCUG 29516 and CCUG 32536 were determined. A comparative sequence analysis of approximately 650 nucleotides (which included diagnostic variable regions $\mathrm{V} 1$ to $\mathrm{V} 3$ ) revealed $100 \%$ similarity among the three strains, which demonstrated their genealogical homogeneity. To determine the generic position of the unidentified bacterium, the $16 \mathrm{~S}$ rRNA sequence of strain CCUG $27294^{\mathrm{T}}$ was compared with the 16S rRNA sequences of other gram-positive bacteria with high $\mathrm{G}+\mathrm{C}$ contents. The unidentified bacterium exhibited high levels of sequence similarity (generally $>90 \%$ ) with species of the genera Actinomyces and Arcanobac-
TABLE 1. Similarity values based on $16 \mathrm{~S}$ rRNA sequences of some Actinomyces and Arcanobacterium spp. and strain CCUG $27294^{\mathrm{T}}$

\% Sequence similarity with
Taxon (EMBL no.)
Actinomyces graevenitzii
CCUG $27294^{\mathrm{T}}$

Actinomyces bovis (X81061).................................................. 93.1

Actinomyces denticolens (X80412)......................................... 92.0

Actinomyces georgiae (X80413) .............................................. 90.7

Actinomyces gerencseriae (X80414).......................................... 91.3

Actinomyces hordeovulneris (X82448) .................................... 90.8

Actinomyces howellii (X80411).............................................. 92.2

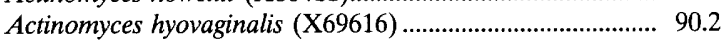

Actinomyces humiferus (X82449) ............................................. 89.7

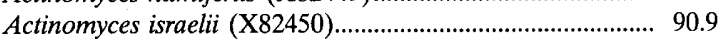

Actinomyces meyeri (X82451)................................................. 90.8

Actinomyces naeslundii (X81062) ........................................ 92.9

Actinomyces neuii subsp. anitratus (X71862) ...................... 88.6

Actinomyces neuii subsp. neuii (X71861)............................ 88.6

Actinomyces odontolyticus (X80504) ..................................... 91.2

Actinomyces radingae (X78719) ............................................ 89.6

Actinomyces slackii (X82452)............................................... 93.8

Actinomyces sp. strain ATCC 49338 (X81063).................... 92.0

Actinomyces suis (S83623) .................................................. 88.7

Actinomyces turicensis (X78720) ............................................ 90.3

Actinomyces viscosus (X82453) ................................................ 92.9

Arcanobacterium bernardiae (X79224) .................................. 90.5

Arcanobacterium haemolyticum (X73952) .............................. 90.4

Arcanobacterium phocae (X97049)......................................... 91.1

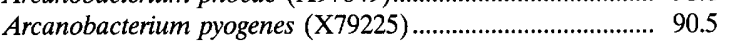

${ }^{a}$ The numbers in parentheses are EMBL 16S rRNA nucleotide sequence accession numbers.

terium (Table 1). Significantly lower levels of relatedness were observed with other actinomycete and coryneform taxa (data not shown). Figure 2 is a tree constructed by the neighborjoining method and shows the phylogenetic relationships of strain CCUG $27294^{\mathrm{T}}$ with Actinomyces spp., Arcanobacterium spp., and some other related high-G+C-content organisms. From the phylogenetic analysis it is clear that the unidentified

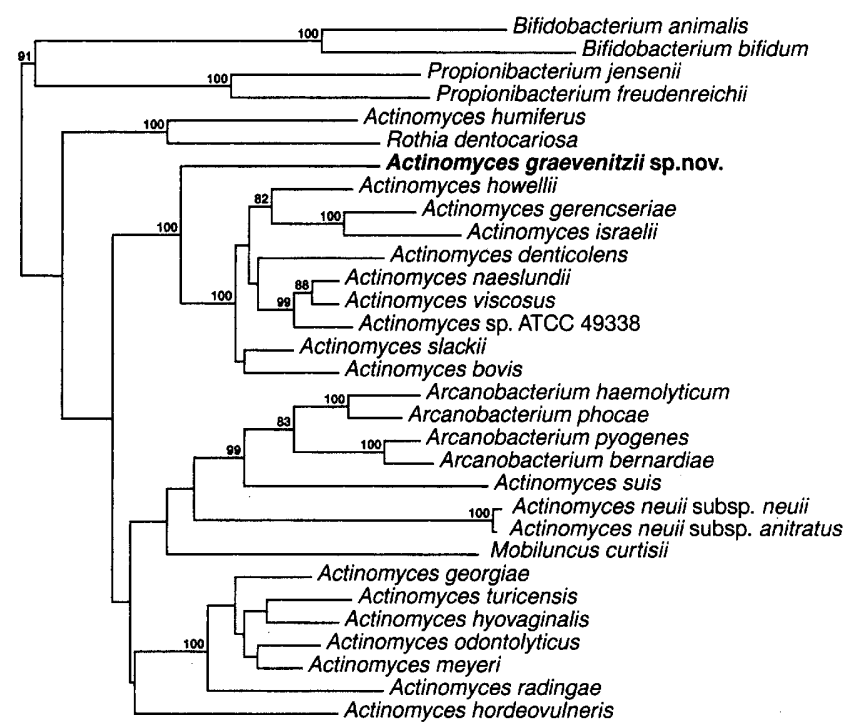

FIG. 2. Unrooted tree showing the phylogenetic relationships of Actinomyces graevenitzii sp. nov, other members of the genus Actinomyces, and related species. The tree, which was constructed by using the neighbor-joining method, was based on a comparison of approximately 1,320 nucleotides. Bootstrap values, expressed as percentages of 500 replications, are indicated at branch points. 
TABLE 2. Characteristics that differentiate Actinomyces graevenitzii from other aerobically growing, catalase-negative Actinomyces spp. isolated from humans ${ }^{a}$

\begin{tabular}{|c|c|c|c|c|c|c|c|c|}
\hline Species & $\begin{array}{l}\text { Nitrate } \\
\text { reduction }\end{array}$ & $\begin{array}{l}\text { Urease } \\
\text { activity }\end{array}$ & $\begin{array}{l}\text { Esculin } \\
\text { hydrolysis }\end{array}$ & $\begin{array}{l}\text { Acid produced } \\
\text { from mannitol }\end{array}$ & $\begin{array}{l}\text { Acid produced } \\
\text { from xylose }\end{array}$ & $\begin{array}{c}\beta \text {-Galactosidase } \\
\text { activity }\end{array}$ & $\begin{array}{c}\alpha \text {-Glucosidase } \\
\text { activity }\end{array}$ & $\begin{array}{l}N \text {-Acetyl- } \beta \text {-glucos- } \\
\text { aminidase activity }\end{array}$ \\
\hline Actinomyces graevenitzii & $--^{b}$ & - & - & - & - & + & - & + \\
\hline Actinomyces georgiae & $\mathrm{V}$ & - & $\mathrm{V}$ & $\mathrm{V}$ & + & ND & ND & ND \\
\hline Actinomyces gerencseriae & $\mathrm{V}$ & - & + & V & + & ND & ND & ND \\
\hline Actinomyces israelii & $\mathrm{V}$ & - & + & $\mathrm{V}$ & + & + & + & - \\
\hline Actinomyces naeslundii & $\mathrm{V}$ & + & + & - & $\mathrm{V}$ & $\mathrm{V}$ & $\mathrm{V}$ & - \\
\hline Actinomyces odontolyticus & + & - & $\mathrm{V}$ & - & V & - & - & - \\
\hline Actinomyces radingae & - & - & + & V & + & + & + & + \\
\hline Actinomyces turicensis & - & - & - & V & + & - & + & - \\
\hline
\end{tabular}

${ }^{a}$ Data from references $6,7,10$, and 11

${ }^{b}-$, negative; + , positive; $\mathrm{V}$, variable; ND, not determined.

bacterium represents a new subline within the genus Actinomyces (8). Although the new bacterium did not exhibit a particularly close phylogenetic affinity with any previously recognized species, it formed a loose and statistically significant association (bootstrap value, 100\%) with a subcluster which included Actinomyces bovis and closely related organisms (Fig. 2). A parsimony analysis was also performed, and all significant groups (Fig. 2) were confirmed (data not shown).

It is evident from both the results of phenotypic and phylogenetic studies that the four clinical isolates which we studied belong to a new species in the genus Actinomyces. Phylogenetically, the new bacterium exhibits a significant association with the Actinomyces bovis cluster of species (8), although the tree topology and sequence divergence values of $>6 \%$ unequivocally demonstrate that the new bacterium is distinct at the species level. The new bacterium from clinical sources can be readily distinguished from other aerobically growing human Actinomyces species by the tests shown in Table 2 . Notable phenotypic features of the new bacterium include the tendency of its colonies to adhere strongly to agar, its production of major amounts of lactic acid from glucose metabolism, and its strong $N$-acetyl- $\beta$-glucosaminidase activity. Based on the phenotypic and phylogenetic distinctiveness of this organism, a new species, Actinomyces graevenitzii, is proposed.

Description of Actinomyces graevenitzii sp. nov. Actinomyces graevenitzii (N. L. gen. n. graevenitzii, of Graevenitz, in honor of Alexander von Graevenitz, contemporary American microbiologist, for his many contributions to clinical microbiology) cells are straight or slightly curved rods that exhibit some branching and have swollen ends. Cells are gram positive, do not form spores, and are nonmotile. Colonies on blood agar incubated in the presence of $5 \% \mathrm{CO}_{2}$ are nonpigmented, opaque, and approximately $0.2 \mathrm{~mm}$ in diameter after $24 \mathrm{~h}$ of incubation. Colonies adhere to agar surfaces. Facultatively anaerobic and catalase negative. Lactic acid and succinic acid are the major end products of glucose metabolism. Acid is produced from glycerol, galactose, fructose, inositol, $N$-acetylglucosamine, maltose, lactose, ribose, sucrose, D-tagatose, and 5-ketogluconate. Acid is not produced from erythritol, D-arabinose, $\mathrm{D}$-xylose, L-xylose, $\beta$-methylxyloside, L-sorbose, rhamnose, dulcitol, mannitol, sorbitol, $\alpha$-methyl-D-mannoside $\alpha$ methyl-D-glucoside, amygdalin, salicin, cellobiose, melibiose, trehalose, inulin, melezitose, amidon, glycogen, xylitol, $\beta$-gentiobiose, D-fucose, L-fucose, D-arabitol, and L-arabitol. Hippurate, esculin, and urea are not hydrolyzed. Nitrate is not reduced. Leucine arylamidase, acid phosphatase, phosphoamidase, $\beta$-galactosidase, and $N$-acetyl- $\beta$-glucosaminidase are produced. Pyrrolidonyl arylamidase, lipase, valine arylamidase, trypsin, chymotrypsin, $\alpha$-galactosidase, $\beta$-glucuronidase, $\alpha$-glu- cosidase, $\beta$-glucosidase, $\alpha$-mannosidase, and $\alpha$-fucosidase activities are not detected. The major cellular fatty acids are $\mathrm{C}_{12: 0}$ (3 to $4 \%$ ), $\mathrm{C}_{14: 0}\left(10\right.$ to $11 \%$ ), $\mathrm{C}_{16: 1 \omega 9}$ (4 to $5 \%$ ), $\mathrm{C}_{16: 0}$ (38 to $40 \%), \mathrm{C}_{18: 1 \omega 9}(28$ to $30 \%)$, and $\mathrm{C}_{18: 0}(6$ to $8 \%)$. Isolated from human clinical specimens (mainly respiratory tract secretions) Habitat is unknown. The type strain is CCUG 27294. The type strain has the characteristics of the species.

Nucleotide sequence accession number. The $16 \mathrm{~S}$ rRNA gene sequence of strain CCUG $27294^{\mathrm{T}}$ has been deposited in the GenBank database under accession no. Y09589.

This work was supported in part by grants ERBCHRX-CT93-0194, BI02-CT93-0119, and BI02-CT94-3098 from the European Union.

We are grateful to G. Funke, University of Zürich, for his contributions to the description of the new species.

\section{REFERENCES}

1. Devereux, J., P. Haeberli, and O. Smithies. 1984. A comprehensive of sequence analysis programs for the VAX. Nucleic Acids Res. 12:387-395.

2. Felsenstein, J. 1989. PHYLIP-phylogeny inference package (version 3.2) Cladistics 5:164-166

3. Funke, G., G. Martinetti-Lucchini, G. E. Pfyffer, M. Marchiani, and A. von Gravenitz. 1993. Characteristics of CDC group 1 and group 1-like coryneform bacteria isolated from clinical specimens. J. Clin. Microbiol. 31:29072912.

4. Funke, G., S. Stubbs, A. Graevenitz, and M. D. Collins. 1994. Assignment of human-derived CDC group 1 coryneform bacteria and CDC group 1-like coryneform bacteria to the genus Actinomyces as Actinomyces neuii subsp. neuii sp. nov., subsp. nov., and Actinomyces neuii subsp. anitratus subsp. nov. Int. J. Syst. Bacteriol. 44:167-171.

5. Funke, G., C. Pascual Ramos, J. F. Garayzabal, N. Weiss, and M. D. Collins 1995. Description of human-derived Centers for Disease Control coryneform group 2 bacteria as Actinomyces bernardiae sp. nov. Int. J. Syst. Bacteriol. 45:57-60.

6. Funke, G., A. von Graevenitz, J. E. Clarridge III, and K. A. Bernard. 1997. Clinical microbiology of coryneform bacteria. Clin. Microbiol. Rev. 10:125159

7. Johnson, J. L., L. V. H. Moore, B. Kaneko, and W. E. C. Moore. 1990 Actinomyces georgiae sp. nov., Actinomyces gerencseriae sp. nov., designation of two genospecies of Actinomyces naeslundii, and inclusion of $A$. naeslundii serotypes II and III and Actinomyces viscosus serotype II in A. naeslundii genospecies 2. Int. J. Syst. Bacteriol. 40:273-286.

8. Pascual, C., G. Foster, and M. D. Collins. 1997. Phylogenetic analysis of the genus Actinomyces based on 16S rRNA gene sequences: description of $A r$ canobacterium phocae sp. nov., Arcanobacterium bernardiae comb. nov., and Arcanobacterium pyogenes comb. nov. Int. J. Syst. Bacteriol. 47:46-53.

9. Pot, B., P. Vandamme, and K. Kersters. 1994. Analysis of electrophoretic whole-organism protein fingerprints, p. 493-521. In M. Goodfellow and A. G. O'Donnell (ed.), Modern microbial methods. Chemical methods in prokaryotic systematics. J. Wiley and Sons, Ltd., Chichester, United Kingdom.

10. Schaal, K. P. 1986. Genus Actinomyces, p. 1383-1418. In P. H. A. Sneath, N. S. Mair, M. E. Sharpe, and J. G. Holt (ed.), Bergey's manual of systematic bacteriology, vol. 2. The Williams \& Wilkins Co., Baltimore, Md.

11. Schaal, K. P. 1992. The genera Actinomyces, Arcanobacterium, and Rothia, p. 850-905. In A. Balows, H. G. Trüper, M. Dworkin, W. Harder, and 
K. H. Schleifer (ed.), The prokaryotes, vol. I. Springer-Verlag, New York, N.Y.

12. Vandamme, P., M. Vancanneyt, B. Pot, L. Mels, B. Hoste, D. Dewettinck, L Vlaes, C. Van Den Borre, R. Higgins, J. Hommez, K. Kersters, J.-P. Butzler, and H. Goossens. 1992. Polyphasic taxonomic study of the emended genus Arcobacter with Arcobacter butzleri comb. nov. and Arcobacter skirrowii sp. nov., an aerotolerant bacterium isolated from veterinary sources. Int. J. Syst. Bacteriol. 42:344-356.

13. Wüst, J., S. Stubbs, N. Weiss, G. Funke, and M. D. Collins. 1995. Assignment of Actinomyces pyogenes-like (CDC coryneform group E) bacteria to the genus Actinomyces as Actinomyces radingae sp. nov. and Actinomyces turicensis sp. nov. Lett. Appl. Microbiol. 20:76-81. 